\title{
Proximal Radio-Ulnar Translocation Associated with Posterior Dislocation of The Elbow in a Child
}

\author{
A Hatzigiannakis*, G Kiziridis, D Voutsas and C Bogiatzis \\ Department of Orthopaedics, University General Hospital of Alexandroupolis, Greece
}

Submission: April 17, 2017; Published: April 25, 2017

*Corresponding author: A Hatzigiannakis, Orthopaedic Doctor, Orthopaedic Department Director Ellis 8, 68100 Alexandroupolis, Greece,

Email: hatz40@yahoo.com

\section{Abstract}

Proximal radioulnar translocation associated with posterior dislocation of the elbow is an extremely rare combination of trauma to the elbow in children, easily overlooked. We report on the successful reduction of both these dislocations in an 11-year-old boy with an additional displaced Salter - Harris type II epiphyseal injury of the proximal radial epiphysis. To our knowledge this is the first case report with these three concomitant injuries.

\section{Introduction}

Dislocation of the elbow in children is a rare injury [1-3] accounting for less than $3-6 \%$ of all elbow injuries. [4]. The convergent type of radioulnar dislocation (or translocation) was first described by Harvey (1979) [5] Since, then 13 articles have

\section{Case Report}

been published, reporting 21 case reports of this injury [4,6-17]. The difficulty, or sometimes inability to recognize the radioulnar translocation in the initial $\mathrm{x}$-rays is the most common problem in these cases, $[5,10-12,14]$ which can lead to a late treatment and finally to a poor functional result [10].

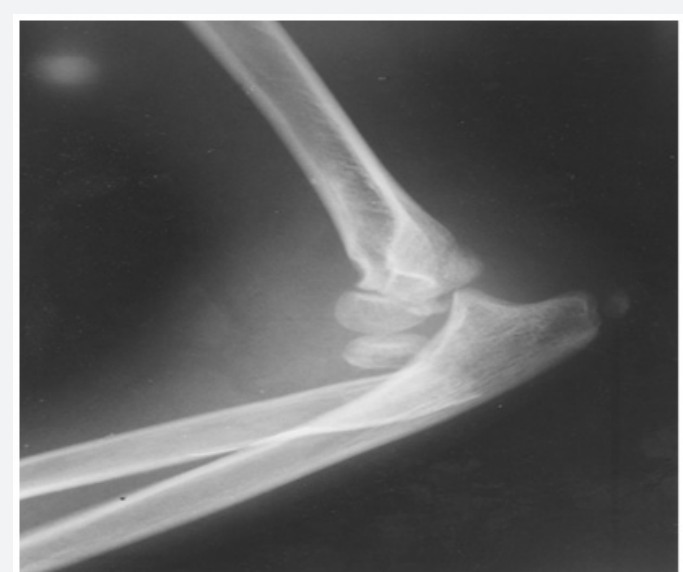

Figure 1A: Lateral radiograph of the left elbow showing a posterior dislocation of the elbow with a complete fracture - separation of the proximal radial epiphysis.

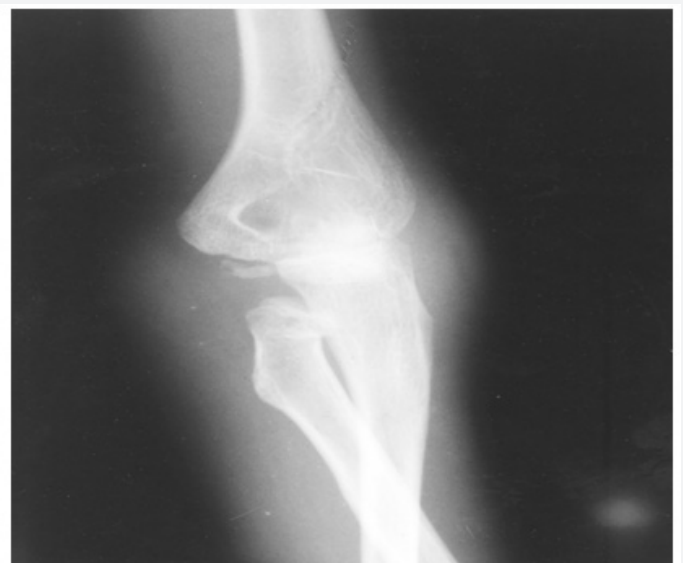

Figure 1B: Anteroposterior radiograph of the left elbow showing the articulation of the ulna with the humeral lateral condyle and the radius with the medial condyle.

Figure 1A \& 1B: Antero posterior and lateral radiograph of the elbow showing the severe injury.

An eleven-year-old boy was admitted to hospital after a fall from a height, landing on his left arm. On examination the elbow was deformed and held in flexion of about $80^{\circ}$. There were no neurovascular deficits. The radiological examination showed a posterior dislocation of the elbow and a displaced Salter - Harris type II epiphyseal injury of the proximal radial epiphysis. The 


\section{Orthopedics and Rheumatology Open Access Journal}

antero posterior radiograph was the cause of a more careful observation of it, where it was found, that the radius and ulna were reversely articulated with the distal humerus (Figures l A \& 1B).

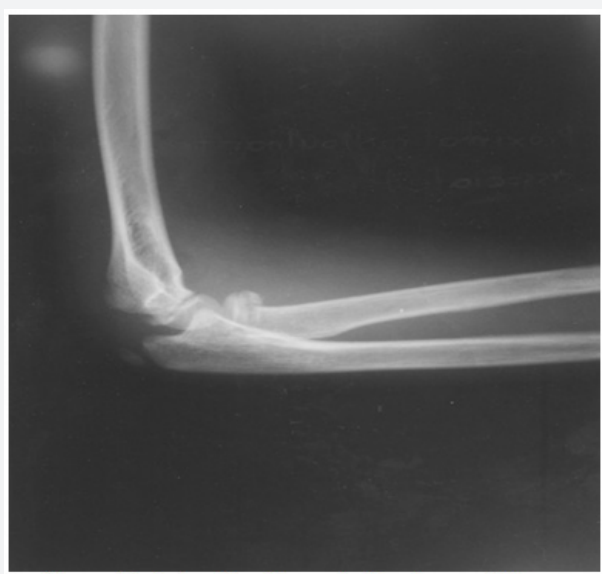

Figure 2A: Lateral radiograph showing partial reduction of the dislocation.

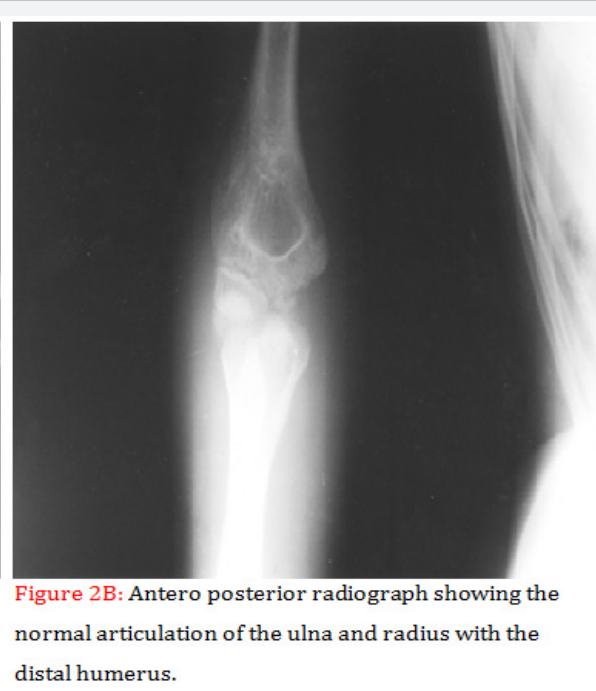

Figure 2A \& 2B: Post-closed reduction radiographs showing partial reduction of the dislocation.

Under general anaesthesia, a great degree of instability of the medial ligamentous structures was noticed. Closed reduction of the dislocation was attempted, but was partially successful (Figures 2A \& 2B). Subsequently, through a lateral incision, an open reduction of the dislocation was performed. The head of the radius was also reduced and fixed with a Kirschner-wire (Figure 3). The arm was splinted in a long cast with the elbow

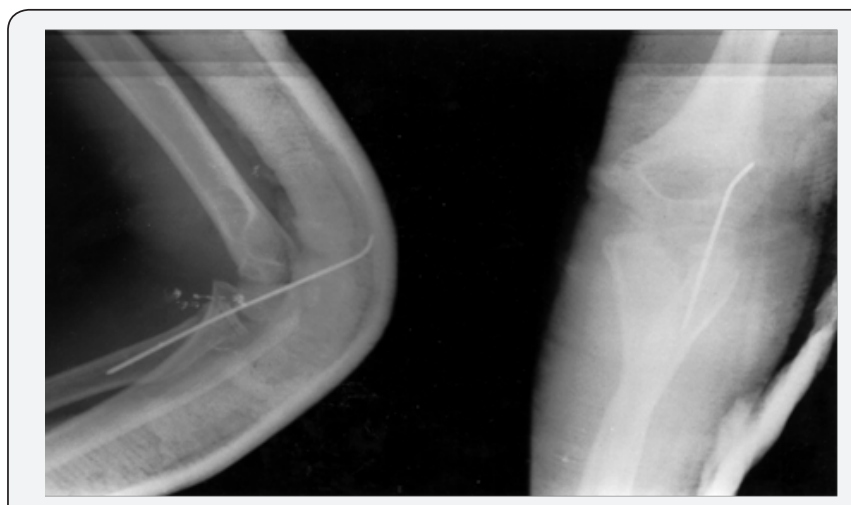

Figure 3: Lateral and anteroposterior radiographs of the elbow after open reduction and stabilization with one Kirschner wire.

\section{Discussion}

Posterior dislocation of the elbow is quite rare in children and it is often associated with fractures of this site Rockwood [18]. Proximal radio ulnar translocation is a very rare injury and it is easily overlooked, although it is recognized by the fact that the radius and the ulna are reversely articulated with the distal humerus. Only rare cases of proximal radio ulnar translocation have been reported in the English literature, all in children. The reason for the presentation of this case is its rarity and additionally the presence of epiphysiolysthesis of the proximal radius Rockwood [18]. at $90^{\circ}$ of flexion. The cast and the K-wire were removed 3 weeks later and active movements of the elbow begun. At 6 months the proximal radial epiphysis had fused with marked callus formation. Three years after the injury, the range of extension / flexion was $5^{\circ} / 160^{\circ}$ and supination / pronation was $50^{\circ} / 55^{\circ}$ and the elbow was stable (Figure 4 ).

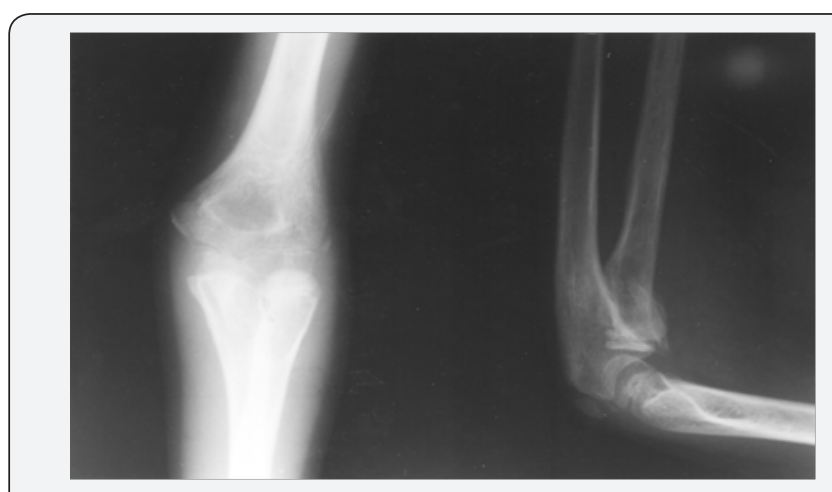

Figure 4: Lateral and antero posterior radiographs 3 years postinjury showing the normal appearance. The radial epiphysis had fused.

Wodecki P et al. [16] reported a similar case recently. Two theories for the cause of this injury have been reported. One supports that this injury is iatrogenic and occurs during reduction of the elbow dislocation with powerful pronation Harvey \& Tchelebi [5]. The other theory tries to explain, that translocation occurs during the initial injury of the elbow Mac Sween \& Carl et al. $[6,8]$.

Isbister [13] believes that the fall on the outstretched hand contributes to a valgus strain of the elbow, resulting in rupture of the medial collateral structures (Figure 5A). Further valgus strain may cause a fracture of the radial neck (Figure $5 B$ ). The 


\section{Orthopedics and Rheumatology Open Access Journal}

proximal radial shaft, then passes between the biceps tendon anteriorly and the ulna posteriorly. The annular ligament is ruptured and finally the ulna passes postero laterally (Figure 5C).

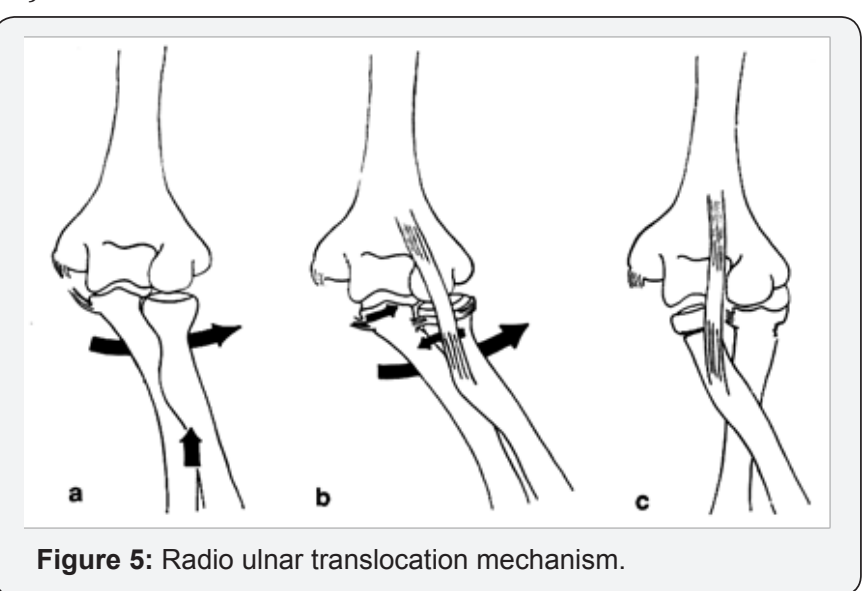

Combourier and his associates (2010) [17] propose that proximal radio ulnar translocation is caused by hyperpronation of the radius with substantial disruption of the ligaments and soft tissues around the proximal radio ulnar joint, especially the annular ligament, adding, that an avulsion of the brachialis anterior tendon is a necessary condition to obtain a medial transposition of the radial head.

In our case, translocation was due to the initial injury, because in the first antero posterior radiograph, no lateral displacement of the forearm bones was observed, but only a crosswise position of the forearm bones, resulting into a change of the articulating positions of the radius and ulna with the distal humerus. During the attempt of closed reduction, while translocation correction was achieved, dislocation reduction was not fully achieved. This possibly occurred because insufficient pressure was exercised to the front of the olecranon during reduction.

A second closed reduction was not attempted and an open reduction and fixation of the displaced proximal epiphysis of the radius was performed. The recognition of this injury requires antero posterior and lateral good-quality radiographs for the certain diagnosis of the elbow dislocation. Harvey \& Tchelebi [5] report that correct diagnosis escaped initially, because elbow radiographs were not of good quality and there was not a real antero posterior radiograph. Also, during reduction of the dislocation, powerful pronation should be avoided and the forearm should be reduced in supination, so that radius and ulna translocation should be avoided. After the reduction, careful $\mathrm{x}$-ray observation should be done in order to ascertain that the two bones are properly articulated with the distal humerus. If proximal radio ulnar translocation associated with an elbow dislocation in a child is immediately diagnosed, despite severe soft tissue injury, it may have a good result.

\section{References}

1. Carlioz H, Abols Y (1984) Posterior dislocation of the elbow in children. J Pediatr Orthop 4(1): 8-12.

2. Jacoby SM, Herman MJ, Morrison WB (2007) Pediatric elbow trauma: an orthopaedic perspective on the importance of radiographic interpretation. Semin Musculoskelet Radiol 11(1): 48-56.

3. Lins RE, Simovitch RW, Waters PM (1999) Pediatric elbow trauma. Orthop Clin North Am 30(1): 119-32.

4. Antonis K, Leonidou OA, Sbonias G (2011) Convergent type proximal radio ulnar translocation complicating posterior elbow dislocation: watch out for dual dislocations in children's elbows. J Pediatr Orthop B 20(3): 138-141.

5. Harvey S, Tchelebi H (1979) Proximal radio-ulnar translocation: a case report. J Bone Joint Surg 61(3): 447-449.

6. MacSween WA (1979) Transposition of radius and ulna associated with dislocation of the elbow in a child. Injury 10(4): 314-316.

7. Carey RP (1984) Simultaneous dislocation of the elbow and the proximal radio-ulnar joint. J Bone Joint Surg Br 66(2): 254-256.

8. Carl A, Prada S, Teixeira K (1992) Proximal radio ulnar transposition in an elbow dislo- cation. J Orthop Trauma 6(1): 106-109.

9. Dubert T, Benkalfate T, Enkaoua E (1991) An unusual dislocation of the elbow: con- vergent dislocation. Rev Chir Orthop Reparatrice Appar Mot 77(6): 435-437.

10. Eklof O, Nybonde T, Karlsson G (1990) Luxation of the elbow complicated by proximal radio-ulnar translocation. Acta Radiol 31(2): 145-146.

11. Galea A (2004) An unusual case of elbow dislocation in a child: crossover of radius and ulna. J Trauma 57(5): 1125-1126.

12. Gillingham BL, Wright JG (1997) Convergent dislocation of the elbow. Clin Orthop Relat Res 340: 198-201.

13. Isbister ES (1991) Proximal radioulnar translocation in association with posterior dislocation of the elbow. Injury 22(6): 479-482.

14. Roberts C, Lee TS, Rooney J (2008) Convergent dislocation of the elbow: report of three cases. J Shoulder Elbow Surg 17(4): 9-13.

15. Saied A, Moussavi AA (2007) Elbow dislocation translocation in a child: a case report. J Shoulder Elbow Surg 16(6): 17-19.

16. Wodecki P, Maiza D, Rozenblum B (2007) Elbow dislocation in children associated with proximal radioulnar translocation. Rev Chir Orthop Reparatrice Appar Mot 93: 190-194.

17. Combourieu B, Thevenin-Lemoine C, Abelin-Genevois K (2010) Pediatric elbow dislocation associated with proximal radio ulnar translocation: a report of three cases and a review of the literature. J Bone Joint Surg Am 92(8): 1780-1785.

18. Rockwood CA, Wilkins KE, Beaty J H (2006) Fractures in Children $\left(4^{\text {th }}\right.$ edn.), Philadelphia : Lippincott, pp. 844. 
This work is licensed under Creative Commons Attribution 4.0 License DOI: $10.19080 /$ OROAJ.2017.06.555689
Your next submission with Juniper Publishers will reach you the below assets

- Quality Editorial service

- Swift Peer Review

- Reprints availability

- E-prints Service

- Manuscript Podcast for convenient understanding

- Global attainment for your research

- Manuscript accessibility in different formats ( Pdf, E-pub, Full Text, Audio)

- Unceasing customer service

Track the below URL for one-step submission https://juniperpublishers.com/online-submission.php 